The Israeli Journal of Aquaculture - Bamidgeh, IJA_72.2020.1231673, 10 pages

CCBY-NC-ND-4.0・https://doi.org/10.46989/001c.21645

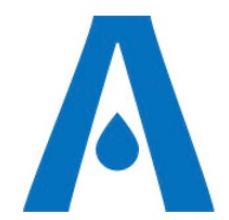

The $I J A$ is a peer-reviewed open-access, electronic journal, freely available without charge to users

Produced by the AquacultureHub non-profit Foundation Sale of IJA papers is strictly forbidden

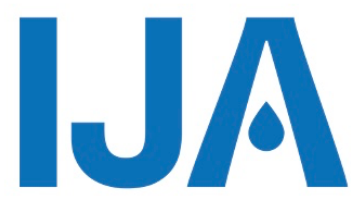

\title{
Effects of dietary P:E ratio and Rhizoclonium in two stocking densities on growth and profitability of Nile tilapia in intensive pond culture
}

\author{
Augusto E. Serrano, Jr.1,2*, Barry Leonard M. Tumbokon², Rosie S. \\ Abalos $^{3}$, Raul de la Peña ${ }^{3}$, Nenia N. Bohulano4, Mac Nhu Binh ${ }^{5}$ \\ ${ }^{1}$ Institute of Aquaculture, College of Fisheries and Ocean Sciences, University of the \\ Philippines Visayas, Miagao, Iloilo, Philippines \\ 2 UP Visayas- National Institute of Molecular Biology and Biotechnology, Miagao, Iloilo, \\ Philippines \\ ${ }^{3}$ College Fisheries, Pangasinan State University, Binmaley, Pangasinan, Philippines \\ ${ }^{4}$ College of Agriculture, Forestry and Environmental Science, Aklan State University, \\ Banga Campus, Aklan, Philippines \\ ${ }^{5}$ Faculty of Fisheries, Hue University of Agriculture and Forestry, Hue, Vietnam
}

Key words: feed cost, green filamentous algae, partial replacement, soybean meal, field trial,

\begin{abstract}
Two onsite tests were carried out to determine the effects of varying dietary protein to energy $(P: E)$ ratio in intensive culture of Nile tilapia in two different places at two stocking densities. In both field trials, three diets were used namely commercial (CM) diet, control (CO) diet containing no Rhizoclonium and a diet containing Rhizoclonium replacing $52 \%$ of soybean meal (RLP); the diets contained decreasing P:E ratio of 21,16 and $12 \mathrm{~g} \cdot \mathrm{MJ}^{-1}$, respectively. The first trial was conducted in Aklan, Philippines at a stocking density of 17 fish. $\mathrm{m}^{-2}$ while the second was in Pangasinan, Philippines at $27 \mathrm{fish} \cdot \mathrm{m}^{-2}$. In both trials, the three diets were fed for 2 months to 3 replicate cages of Nile tilapia, all of which were randomly placed in about 1.0 ha fresh water fish pond. In the first trial in Aklan, at 17 fish $\mathrm{m}^{-2}$ stocking density, no significant differences in the parameters were observed except in the absolute growth rate (AGR) in which the RLP dietary treatment exhibited a higher value than did either the CM or the $\mathrm{CO}$ diet. In Pangasinan, at 27 fish $\mathrm{m}^{-2}$ stocking density, significant differences in TFI, DFI and SGR were observed, all the other parameters were statistically similar. The RLP group exhibited lower total feed intake (TFI) and daily feed intake (DFI) but higher specific growth rate (SGR) than did either the $\mathrm{CM}$ or $\mathrm{CO}$ diet. In either stocking densities, feed cost was the main determinant of profitability in which the RLP group resulted in significantly highest profitability i.e., lowest total production cost, highest gross income and highest profit and profit margin. Although profit was significantly higher in the higher stocking density, profit margin was significantly higher in the lower stocking density. There was no statistical interaction between dietary treatment and stocking density as analyzed by two-way analysis of variance.
\end{abstract}

* Corresponding author. A.E. Serrano Jr, e-mail: aeserrano@up.edu.ph 


\section{Introduction}

Tilapia is the second largest farmed fish group after carp demonstrating a fast growth in the last decade (FAO, 2018). More than a hundred countries grow tilapia at various stocking densities and in various production system. The majority of production of Nile tilapia is in Southeast Asia and they are grown mostly in extensive and semi-intensive ponds where the farm gate price is low thus posing a challenge to its economic viability. Feed is the largest expenditure for tilapia culture, representing about $70 \%$ of total operating cost (Yuan et al., 2017). In 2015, 90\% of the global tilapia production was based on commercial foodstuffs supply and it is expected to increase by $95 \%$ by 2020 and $100 \%$ by 2025 (Tacon and Metian, 2013).

The relationship between protein and energy $(P: E)$ is a key factor for the formulation of fish quality diets (NRC, 2011) and can affect growth performance, feed efficiency and body composition of fish at very low or high levels (Wang et al., 2016). Feed cost depends largely on the crude protein content of the diet and most commercial diets have a dietary digestible protein to digestible energy (DP:DE) ratio of $18-23 \mathrm{~g} \mathrm{MJ}^{-1}$ complying with the recommendation of NRC (1993 and 2011). Since in most formulated diets, protein and energy digestibility are similar, the optimal range in DP:DE is similar to the P:E ratio (Kabir et al., 2019). Excess of non-protein energy can reduce feed intake and limit the use of other nutrients (De la Higuera, 2001) while diets containing high DP:DE ratio promote lower growth since part of the catabolized protein is used for an additional energy source to satisfy body maintenance (NRC, 2011). On the other hand, a phenomenon called 'protein sparing effect' has been demonstrated in several species' diets in which the use of protein as an energy source is minimized thus allowing for greater efficiency and tissue protein deposition (Haidar et al., 2018; Kaushik and Oliva Teles, 1985; Kim \& Kaushik, 1992).

The NRC recommendation for the optimal DP:DE ratio is based on studies done in tanks in the absence of natural food which can still contribute $40-68 \%$ to the production as was measured in shrimps (Porchas-Cornejo et al., 2012). Carneiro et al. (2020) summarize various findings on P:E ratios of Nile tilapia diet with a range of $18.60 \mathrm{~g} \cdot \mathrm{MJ}^{-1}$ to $26.87 \mathrm{~g} \cdot \mathrm{MJ}^{-}$ ${ }^{1}$. In ponds, tilapia yield in semi-intensive culture system was better with a diet of P:E ratio $14 \mathrm{~g} \cdot \mathrm{MJ}^{-1}$ compared with P:E ratio $18 \mathrm{~g} \cdot \mathrm{MJ}^{-1}$ (Kabir et al., 2019a).

Rhizoclonium riparium var. implexum is a green macroalgae that belongs to the Ulvophytes that are diverse morphologically and ecologically (Berger \& Kaever 1992). It grows year round with specific growth rate range from 2.1 to $10.4 \%$ per day (Chao et al 2005). It has a very wide salinity tolerance which ranges from 0.1 to $34 \%$ o (Imai et al 1997). The dried seaweed meal has a crude protein content of $13.9 \%-15.6 \%$, and nitrogen-free extract of 28.8-32.2\% (Bunda et al., 2015) indicating that it can be a protein and carbohydrate supplement. It has an essential amino index (EAAI) 1.02 for the Nile tilapia indicating that it has a relatively balanced essential amino acid content (Bunda et al., 2015). It was demonstrated that $12.6 \%$ Rhizoclonium meal in the diet of the Nile tilapia could replace $45 \%$ of soybean meal and resulted in a significantly higher final average body weight than the control diet containing no seaweed supplement (Cabanero et al., 2016). Protein concentrate of Rhizoclonium riparium could also be used at $12.6 \%$ with $1.5 \%$ lysine supplementation (Cabanero et al., 2016b).

The present study aimed to evaluate onsite the effects of dietary $P: E$ ratio, Rhizoclonium meal at two stocking densities in two different sites of Nile tilapia culture system.

Preparation of experimental feeds

\section{Materials and Methods}

Three diets which contained three levels of P:E ratios were prepared (Table 1). CM was a commercial diet and $\mathrm{CO}$ was a formulated control diet and both contained similar crude protein (CP) content of 348 and $349 \mathrm{~g} \cdot \mathrm{kg}^{-1} \mathrm{DM}$, respectively; RLP (Rhizoclonium, low protein diet) was a formulated experimental diet $13 \%$ containing green filamentous algae (Rhizoclonium riparium) meal replacing $52 \%$ of the soybean meal of the $\mathrm{CO}$ diet and higher copra meal and rice bran to lower the CP content to $242 \mathrm{~g} \cdot \mathrm{kg}^{-1} \mathrm{DM}$. However, both CO and RLP diets contained similar gross energy (GE) of 22 and $21 \mathrm{~g} \cdot \mathrm{kg}^{-1}$ DM both higher than the 
GE of the CM diet of $17 \mathrm{~kJ} \cdot \mathrm{g}^{-1} \mathrm{DM}$. Overall, the experimental diets CM, CO and RLP all differed in their P:E ratios of 21,16 and $12 \mathrm{~g} \mathrm{CP} \cdot \mathrm{MJ}^{-1} \mathrm{GE}$.

Rhizoclonium riparium was collected from Panay, Capiz and Leganes, Iloilo in the Philippines. After drying, the algae were oven dried, pulverized and were incorporated in the RLP diet. The composition of the feed used in both the Aklan (located in Central Philippines) and Pangasinan (located in the Northern Philippines) sites in the are shown in Table 1.

Table 1 Composition of CM, CO and RLP feeds used in the first pilot tests done in Makato, Aklan. The ingredient composition of the commercial diet is proprietary but the proximate composition was analyzed.

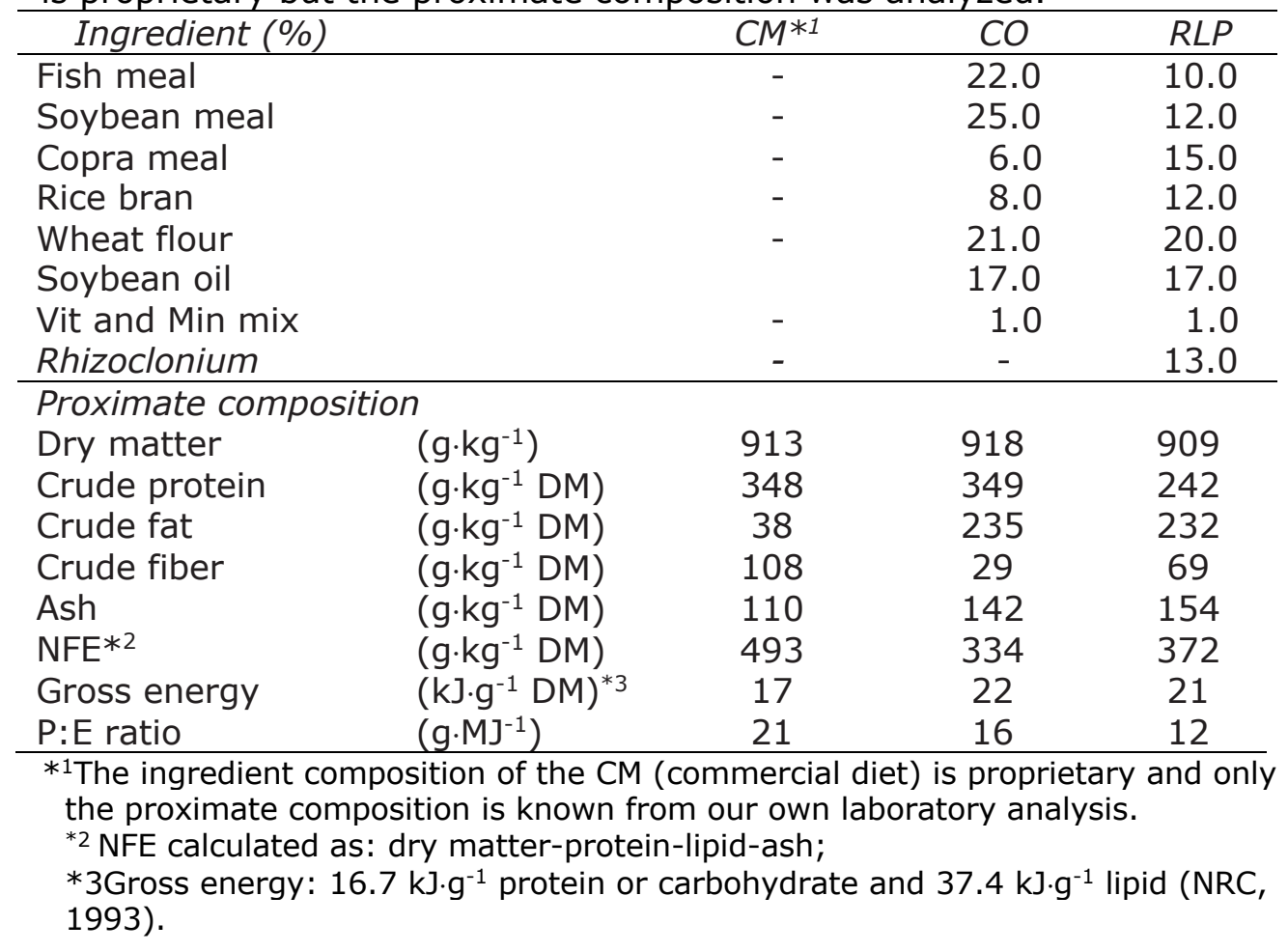

Feeding trial in intensive culture system in Aklan, Philippines

The growth trial was conducted in bottom-netted cages ( $3 \mathrm{~m}^{2}$ surface and $1.50 \mathrm{~m}$ height). The cages were made with polyethylene mesh $(15 \times 20 \mathrm{~mm}$ aperture $)$ and they were weighed down by weights to the bottom sediment. The stocking density used in this site was $17 \mathrm{fish} \cdot \mathrm{m}^{-2}$. Six hundred (600) Nile tilapia with mean weight of $35.8 \mathrm{~g}$ were distributed into 12 cages in which CM, CO and RLP diet groups were replicated three times with additional 3 cages for the 'no feed' treatment; the latter treatment was used to estimate the contribution of natural productivity to the growth of the experimental Nile tilapia. The feeds offered daily started at $10 \%$ body weight with the assumption of daily specific growth rate (SGR) of $1 \%$ and the trial lasted for 60 days.

Feeding trial in intensive system in Pangasinan, Philippines

The net cages used in this site were similar to those used in Aklan, Philippines. Nine hundred sixty (960) Nile tilapia juveniles with a mean average weight of $64.2 \mathrm{~g}$ were purchased from the Pangasinan State University-Binmaley Campus hatchery and were divided into 12 net cages with the same dimension as that used in Aklan, with 80 fish in each cage at a higher stocking density of 26 fish. $\mathrm{m}^{-2}$ than that in Aklan. The feeding trial lasted for 63 days.

\section{Growth and efficiency parameters}


The growth and efficiency parameters measured in both sites were the following:

Survival Rate $(\%)=100 *$ (Total no. of live fish $) /($ Total no. of fish stocked $)$

$$
\text { Weight Gain }(g)=\text { FABW- IABW }
$$

Specific growth rate $\left(\mathrm{SGR} ; \%\right.$ day $\left.^{-1}\right): \mathrm{SGR}=100 *[\operatorname{lnWf}-\operatorname{lnWi}] / \mathrm{t}$ (days)

Daily feed intake (DFI, \% $\mathrm{d}^{-1}$ ) $=100 *$ [Supplied feed /Average Biomass]/ $\mathrm{t}$ (days)

Feed Conversion Ratio $(F C R)=($ Total Individual Feed Intake)/ (Weight Gain)

$$
\operatorname{AGR}\left(g \cdot d^{-1}\right)=(W f-W i) / t
$$

Where AGR is absolute growth rate.day ${ }^{-1}$

$\mathrm{CNP}=100 *[(\mathrm{Wf}-\mathrm{Wi})$ unfed fish $/(\mathrm{Wf}-\mathrm{Wi})$ fed fish $]$

\section{Economic evaluation}

The cost of each feed per $\mathrm{kg}$ were US\$ 0.76 , US\$ 0.65 and US\$ 0.59 for CM, CO and RLP, respectively. The unit cost of Nile tilapia juvenile initially stocked was US\$0.08. The assumption for fish sales was that all harvested fish were sold by the same fish price, US\$ $1.73 \cdot \mathrm{kg}^{-1}$. The estimations were based on farmgate prices. The fixed costs were disregarded because they would not vary according to stocking density and the sum of feed cost and fish cost was considered as the total cost. Economic profitability was assessed according to the following formulas, all projected to one ha production.
a) Total costs of production (TC) $=$ cost of fish stock + cost of feed
b) Gross income $(\mathrm{GI})=$ total fish output $x$ sales price
c) Profit $(P)=G I-T C$
d) Profit margin $=100 *(P / T C)$

\section{Statistical Analyses}

Growth performance of Nile tilapia in different experimental groups were compared by One-way ANOVA $(\alpha=0.05)$, using the SPSS statistical package version 16.0. A two-way ANOVA was used to analyze whether there was significant interaction between dietary $P: E$ ratio and stocking density $(\alpha=0.05)$. Data were presented as mean \pm standard error mean (SEM) and each parameter was tested for normality of distribution and homogeneity of variances before performing ANOVA. Post-hoc analyses were done using Duncan's Multiple Range Test (DMRT) to identify differences between the independent factors.

\section{Growth and feed efficiency performance}

\section{Results}

In the Aklan field trial where a lower stocking density (17 fish. $\mathrm{m}^{-2}$ ) was used, only parameters on feed consumption and growth rate exhibited significant differences among dietary treatments i.e., DFI and AGR (Table 2). Daily feed consumption (i.e., DFI) was significantly lowest in the RLP group while growth rate (i.e., AGR) was significantly highest; the CM and CO groups exhibited significantly higher DFI and lower AGR and were not significantly different from each other $(p>0.05)$. These two parameters contributed well in a higher profitability of the RLP group as reflected in Tables 4 and $\mathbf{5}$. The FCR, SGR, survival rate and CNP values did not vary significantly among the three dietary treatments $(p>0.05)$.

In the Pangasinan trial where a higher stocking density ( 27 fish $\cdot \mathrm{m}^{-2}$ ) was used, similar with the Aklan trial outcome, feed consumption, growth rate and CNP were the parameters 
that exhibited significant differences between dietary treatments i.e., TFI, DFI and SGR. Both RLP and CO groups exhibited significantly lower TFI and CNP values and significantly higher SGR value than did the CM group $(p<0.05)$ (Table 3). Again, these parameters on lower feed consumption and higher growth rate would translate into higher profitability of the RLP group as reflected on Tables 4 and 5. WG, FCR, AGR and survival rate did not differ significantly among the dietary treatments $(p>0.05)$.

Table 6 summarizes the comparison between the growth and efficiency indices of Nile tilapia between two stocking densities in the Aklan (17 fish $\mathrm{m}^{-2}$ ) and Pangasinan (27 fish $\cdot \mathrm{m}^{-2}$ ) feeding trials. DFI, SGR and AGR values were all nearly 2 -fold higher in the lower stocking density (Aklan) than those in the higher stocking density (i.e., Pangasinan trial) while FCR values were statistically similar. Conversely, CNP was $41 \%$ lower in the lower stocking density than in the higher stocking density. We tried to determine whether or not there was significant interaction between $\mathrm{P}$ : E ratio and stocking density by conducting a two-way ANOVA but there was none ( $p>0.05$, data not shown).

Table 2 Growth and efficiency performance of Nile tilapia cultured intensively (17 fish.m${ }^{2}$ ) in Aklan, Philippines fed either CM, CO or RLP diet for $60 \mathrm{~d}$.

\begin{tabular}{lrrrrrrrrrr}
\hline $\operatorname{Diet}(P: E)$ & $\begin{array}{r}I B W \\
(g)\end{array}$ & $\begin{array}{r}\text { TFI } \\
(g)\end{array}$ & $\begin{array}{r}\text { DFI } \\
\left(\% d^{-1}\right)\end{array}$ & $\begin{array}{r}F B W \\
(g)\end{array}$ & $\begin{array}{r}\text { WG } \\
(g)\end{array}$ & $\begin{array}{r}F C R \\
(g)\end{array}$ & $\begin{array}{r}S G R \\
\left(\% d^{1}\right)\end{array}$ & $\begin{array}{r}A G R \\
g . d^{-1}\end{array}$ & $\begin{array}{r}\text { Surv } \\
(\%)\end{array}$ & $\begin{array}{r}\text { CNP } \\
\%\end{array}$ \\
\hline CM $(21)$ & 35.0 & 187.2 & $2.0^{\mathrm{a}}$ & $136.4^{\mathrm{a}}$ & $101.4^{\mathrm{b}}$ & 1.85 & 2.28 & $1.69^{\mathrm{b}}$ & 100 & 15.52 \\
CO $(16)$ & 33.7 & 188.8 & $2.3^{\mathrm{ab}}$ & $121.2^{\mathrm{b}}$ & $96.2^{\mathrm{b}}$ & 1.96 & 2.14 & $1.60^{\mathrm{b}}$ & 100 & 16.93 \\
RLP $(12)$ & 38.6 & 181.5 & $1.9^{\mathrm{b}}$ & $141.3^{\mathrm{a}}$ & $111.0^{\mathrm{a}}$ & 1.73 & 2.26 & $1.84^{\mathrm{a}}$ & 100 & 14.78 \\
\hline
\end{tabular}

Superscripts with different letter/s indicate significant differences between diets ( $<<0.05$ ). All data are for individual fish except that of survival rate. IBW = initial body weight; TFI = total feed intake; DFI = daily feed intake; FBW = final body weight; $W G=$ weight gain; $F C R=$ feed conversion ratio; $S G R=$ specific growth rate; $A G R=$ absolute growth rate; $\mathrm{CNP}=$ contribution of natural productivity.

Table 3 Growth and efficiency performance of Nile tilapia cultured in intensive system (27 fish. $\mathrm{m}^{2}$ ) in Pangasinan, Philippines fed either CM, CO or RLP diets for $64 \mathrm{~d}$.

\begin{tabular}{lllllllllll}
\hline Diet $(P: E)$ & $\begin{array}{l}I B W \\
(g)\end{array}$ & $\begin{array}{l}\text { TFI } \\
(g)\end{array}$ & $\begin{array}{l}\text { DFI } \\
\% d^{-1}\end{array}$ & $\begin{array}{l}F B W \\
(g)\end{array}$ & $\begin{array}{l}\text { WG } \\
(g)\end{array}$ & FCR & $\begin{array}{l}\text { SGR } \\
\left(\% d^{-1}\right)\end{array}$ & $\begin{array}{l}A G R \\
g . d^{-1}\end{array}$ & $\begin{array}{l}\text { Surv. } \\
(\%)\end{array}$ & $\begin{array}{l}C N P \\
(\%)\end{array}$ \\
\hline CM (21) & 70.7 & $301.7^{\mathrm{b}}$ & $1.4^{\mathrm{a}}$ & 100.0 & 39.8 & 2.4 & $0.6^{\mathrm{b}}$ & 0.5 & 77.1 & $38.90^{\mathrm{a}}$ \\
CO (16) & 57.8 & $294.3^{\mathrm{ab}}$ & $1.2^{\mathrm{ab}}$ & 117.0 & 56.5 & 1.9 & $1.0^{\mathrm{ab}}$ & 0.9 & 83.8 & $26.13^{\mathrm{b}}$ \\
RLP (12) & 64.3 & $262.0^{\mathrm{a}}$ & $0.8^{\mathrm{c}}$ & 120.8 & 59.3 & 1.3 & $1.1^{\mathrm{a}}$ & 0.9 & 94.2 & $24.90^{\mathrm{b}}$ \\
\hline
\end{tabular}

Superscripts with different letter/s indicate significant differences between diets $(p<0.05)$.

Table 4 Actual economic profitability per cage of intensive culture of Nile tilapia pilot tested in Aklan and Pangasinan, Philippines at two stocking densities.

\begin{tabular}{|c|c|c|c|c|c|c|}
\hline & \multicolumn{3}{|c|}{ Aklan (17 fish $\left.\cdot m^{-2}\right)$} & \multicolumn{3}{|c|}{ Pangasinan (27 fish $\mathrm{m}^{-2}$ ) } \\
\hline $\begin{array}{l}\text { Diet } \\
(P: E)\end{array}$ & $\begin{array}{r}F C \cdot \text { cage }^{-1} \\
\text { (US } \$)\end{array}$ & $\begin{array}{r}\text { GI. cage } \text { ca }^{-1} \\
\text { (US } \$ \text { ) }\end{array}$ & $\begin{array}{l}P \cdot \text { cage }^{-1} \\
\text { (US\$) }\end{array}$ & $\begin{array}{c}F C \cdot \text { cage }^{-1} \\
\text { (US\$) }\end{array}$ & $\begin{array}{c}\text { GI. } \text { cage }^{-1} \\
\text { (US\$) }\end{array}$ & $\begin{array}{c}P \cdot \text { cage }^{-1} \\
\text { (US\$) }\end{array}$ \\
\hline CM (21) & $7.13^{a}$ & $11.81^{b}$ & $3.23^{b}$ & $5.60^{\mathrm{a}}$ & 10.82 & 4.42 \\
\hline CO (16) & $6.09 \mathrm{~b}$ & $10.48^{b}$ & $3.37^{b}$ & $4.89^{a}$ & 12.17 & 7.28 \\
\hline RLP (12) & $5.87^{b}$ & $12.23^{a}$ & $5.00^{a}$ & $3.52^{b}$ & 14.10 & 10.58 \\
\hline
\end{tabular}

Superscripts with different letter/s indicate significant differences between diets $(p<0.05)$. Feed cost (FC) $\cdot \mathrm{cage}^{-1}=\mathrm{FBW} *$ feed cost: US $\$ 0.76 \cdot \mathrm{kg}^{-1}$ of CM diet; US $\$ 0.65 \cdot \mathrm{kg}^{-1}$ for the CO, and US $\$ 0.62 \cdot \mathrm{kg}^{-1}$ for the RLP; Gross Income (GI) cage $^{-1}=\mathrm{FBW}^{*}$ survival number* US\$1.54 (gate farm price of $1 \mathrm{~kg}$ tilapia); Profit $(P) \cdot$ cage $^{-1}=\mathrm{GI} \cdot \mathrm{cage}^{-1}-\mathrm{FC} \cdot \mathrm{cage}^{-1}$ with the exclusion of other fixed costs such as labor, cost of tilapia juvenile, etc. (1 US Dollar (US\$) $=52.0$ Philippine peso).

Table 5 Projected economic evaluation of Nile tilapia production in one ha using CM, CO or RLP diet in two stocking densities considering all harvested fish sold by the same price (US\$1.73. $\mathrm{kg}^{-1}$ ). 


\begin{tabular}{|c|c|c|c|c|}
\hline \multirow[t]{3}{*}{ Parameters } & \multicolumn{3}{|c|}{$\begin{array}{c}\text { Diet } \\
P: E \text { ratio }\left(g \cdot M J^{-1}\right)\end{array}$} & \multirow{3}{*}{$\begin{array}{c}C V \\
(\%)\end{array}$} \\
\hline & $C M$ & $\mathrm{CO}$ & $R L P$ & \\
\hline & 21 & 16 & 12 & \\
\hline \multicolumn{5}{|l|}{ A. Aklan } \\
\hline Fish stock cost (US\$.ha-1) & $9,615^{a}$ & $9,615^{a}$ & $9,615^{a}$ & \\
\hline Feed cost (US\$.ha-1 $\left.{ }^{-1}\right)$ & 23,760 a & 20,385 b & $19,615^{b}$ & 13.4 \\
\hline Total prod. Cost (US\$.ha-1) & 33,375 a & $29,976^{a}$ & $27,851^{a}$ & 9.2 \\
\hline Gross income (US\$.ha-1) & 39,333 a & $34,931^{b}$ & 40,742 a & 7.9 \\
\hline Profit (US\$.ha-1) & 5,959 b & 4,946 b & 11,512 a & 24.5 \\
\hline Profit margin (\%) & $65.8^{b}$ & $72.1^{b}$ & $123.5^{a}$ & 36.4 \\
\hline \multicolumn{5}{|l|}{ B. Pangasinan } \\
\hline Fish stock cost (US\$.ha-1) & $20,513^{a}$ & $20,513^{a}$ & $20,513^{a}$ & \\
\hline Feed cost (US\$.ha-1) & 39,426 a & 35,755 a & $32,608^{b}$ & 11.8 \\
\hline Total prod. Cost (US\$.ha-1) & 60,605 a & 56,268 ab & $53,121^{c}$ & 6.0 \\
\hline Gross income (US\$.ha-1) & $68,284^{a}$ & 69,749 a & $78,450^{b}$ & 7.6 \\
\hline Profit (US\$.ha-1) & $7,678^{c}$ & $13,481^{b}$ & 25,329 a & 34.4 \\
\hline Profit margin $(\%)$ & $13.1^{\mathrm{c}}$ & $24.0^{b}$ & $47.8^{a}$ & 62.9 \\
\hline
\end{tabular}

Table 6 Summary of comparison of growth and efficiency indices of Nile tilapia cultured at two stocking densities in Aklan and Pangasinan, Philippines.

\begin{tabular}{lccc}
\hline Parameter & Mean value of the dietary treatments & $\begin{array}{c}\text { Fold inc. (17 } \\
\text { fish } \cdot m^{-2} / 27 \\
\left.\text { fish } \cdot m^{-2}\right)\end{array}$ \\
\hline & $\begin{array}{c}\text { 27 fish } \cdot m^{-2} \\
\left(\text { fish } \cdot m^{-2}\right.\end{array}$ & \\
\hline DFI $\left(\% \mathrm{~d}^{-1}\right)$ & 2.07 & 1.13 & 1.83 \\
FCR & 1.85 & 1.87 & 0.99 \\
SGR $\left(\% \mathrm{~d}^{-1}\right)$ & 2.23 & 0.9 & 2.48 \\
AGR $\left({\left.\mathrm{g} . \mathrm{d}^{-1}\right)}_{\text {CNP }(\%)}\right.$ & 1.71 & 0.77 & 2.22 \\
\hline
\end{tabular}

\section{Profitability}

In the Aklan feeding trial, GI.cage ${ }^{-1}$ and the estimated GI.ha- ${ }^{-1}$ were significantly higher in the CM and RLP groups than in the CO group. However, FC.cage ${ }^{-1}$ and estimated FC. ha- ${ }^{-1}$ were significantly lower in CO and RLP groups than in CM group $(p<0.05)$ (Table 5). Given that although total production costs were not significantly different among the treatments, GI was significantly higher in the CM and RLP groups but FC were significantly higher in $C M$, then it followed that P.cage ${ }^{-1}$ (also the projected P.ha ${ }^{-1}$ ) was significantly highest in the RLP group. Feeding Nile tilapia with RLP diet at stocking rate of 17 fish. $\mathrm{m}^{-2}$ resulted in an estimated profit.ha-1 of US\$11,512; this was US\$ 6,566 higher than the P from the CO group and US\$5,553 higher than the $\mathrm{P}$ of the CM group.

In the Pangasinan feeding trial, FC. cage $^{-1}$ and the projected FC.ha ${ }^{-1}$ were significantly lower in RLP group than in either the CM group or the CO group $(p<0.05)$ (Table 5). P.cage $^{-1}$, GI.cage ${ }^{-1}$, estimated GI.ha ${ }^{-1}$ of the three dietary groups were not significantly different from each other $(p>0.05)$. Thus, only the TFI and DFI, and thus FC, significantly differed among the three dietary treatments while the GI values were not significantly different. Following this observation, the estimated $P$, being the difference between FC and GI, was therefore significantly different. The RLP group at stocking density of 27 fish. $\mathrm{m}^{-2}$ resulted in significantly highest estimated $P \cdot h a^{-1}$ of $\$ \cup S 25,329$. The estimated $P$ realized 
from the CM group was significantly lowest at $\$ \cup S 7,678$ and that from the CO group was intermediate between RLP and CM (\$US 13,481).

\section{Discussion}

We investigated the effect of dietary $P$ : $E$ ratio on fish performance and on profitability of intensive culture of Nile tilapia. The low P:E ratio RLP diet (12 g.protein $\left.\mathrm{MJ}^{-1}\right)$ performed better than high $\mathrm{P}: \mathrm{E}$ ratio $\mathrm{CM}\left(21 \mathrm{~g}\right.$ protein $\left.\mathrm{MJ}^{-1}\right)$ in terms of $A G R$. The diet with intermediate P:E ratio (i.e., 16 g.protein $\mathrm{MJ}^{-1}$ in $\mathrm{CO}$ ) diet resulted in intermediate parameter values which sometimes were statistically similar with either the RLP or the CM under intensive culture of 17 fish. $\mathrm{m}^{-2}$ in Aklan. However, under a higher stocking density of 27 fish $\mathrm{m}^{-2}$ in Pangasinan, the superiority of the low P:E ratio RLP diet over the high P:E ratio CM diet became more pronounced in terms of TFI, DFI and SGR. The diet with intermediate $P$ :E ratio (i.e., CO diet) resulted in intermediate indices, again were sometimes statistically similar with either the RLP or the CM diets. The P:E ratio of better performed diet was lower than the recommended $\mathrm{P}: \mathrm{E}$ ratios of $18-23 \mathrm{~g} \cdot \mathrm{MJ}^{-1}$ for Nile tilapia (El-Sayed and Teshima, 1992; Kaushik et al., 1995; NRC, 1993). Other studies showed varying ratios e.g., $19.10 \mathrm{~g} \cdot \mathrm{MJ}^{-1}$ (Carneiro et al., 2020), $16 \mathrm{~g} \cdot \mathrm{MJ}^{-1}$ (Haidar et al., 2018) and $14 \mathrm{~g} \cdot \mathrm{MJ}^{-1}$ (Kabir et al., 2019b) also in Nile tilapia. The CP and GE values in Haidar et al. (2018) recommended diet CP content was $382 \mathrm{~g} \cdot \mathrm{kg}^{-1}$ and $23.5 \mathrm{~kJ} \cdot \mathrm{g}^{-1}$, respectively, which was close to the values in the present study, differing only by about $9 \%$ less for CP and $10 \%$ less for GE. The values gathered by Kabir et al. (2019a) differed greatly from those of Haidar et al. (2018) and from those in the current study. Higher growth of the RLP group could be attributed to the protein-sparing effect that energy provides as was documented in catfish Rhamdia quelen (Meyer and Fracalossi, 2004), red tilapia (Da Silva et al., 1991) and Nile tilapia (NRC, 2011; Fernandez et al., 2016). Meurer et al. (2007) reported that a decrease in growth was observed in animals that received diets combining low protein and low energy and also diets containing high protein and high energy.

In diets containing low CP levels, dietary carbohydrates are higher which can reduce the energy intake of Nile tilapia (Carneiro et al., 2020; Haidar et al., 2018; Saravanan et al., 2012a,b). In the present study, the low P:E ratio diet (i.e., RLP) contained an intermediate level of carbohydrate (NFE content of $37.2 \%$ ) compared with either CM (49.3\% NFE) or CO (33.4\% NFE). Thus, it was probably the high carbohydrate content of the CM diet that impacted negatively on the performance of Nile tilapia. In contrast, the replacement of $52 \%$ soybean meal by Rhizoclonium riparium meal could have contributed substantially to the better outcome of the RLP group since we have demonstrated previously that at $12.6 \%$ inclusion level of Rhizoclonium riparium meal ( $13 \%$ in the present study) replacing $45 \%$ of soybean meal resulted in higher FABW, WG, PER and better FCR than the diet containing no seaweed meal in the Nile tilapia (Cabanero et al., 2016).

The best digestible CP (DP) level reported by Carneiro et al. (2020) for adult tilapia (200-450 g) in a recirculating system was approximately $240 \mathrm{~g} \cdot \mathrm{kg}^{-1}$ DP as estimated using polynomial regression analysis. This was almost the same with the CP level of the RLP diet of $242 \mathrm{~g} \cdot \mathrm{kg}^{-1}$ in the present study. They also observed that higher dietary CP level than this optimum level decreased fish growth, demonstrating that when protein requirement is exceeded, growth rate decreased. This explains why either the AGR in the Aklan trial or the SGR of the Pangasinan trial were superior in the RLP group to either CM or CO group. In addition, feeding diet with high dietary $\mathrm{CP}$ levels like the $\mathrm{CM}$ and $\mathrm{CO}$ diets containing $35 \%$ in the present study, low fish growth can be attributed to the additional energy costs for nitrogen excretion, which demands a high metabolic cost to fish as reported in other studies (Fernandez et al., 2016; Koch et al., 2017).

Except for studies on biofloc system, some of the comparison made above are with studies on Nile tilapia cultured in clear, recirculating water or production systems in which the natural productivity of the pond is not included. This is ignoring a resource that can generate a reduction in the production costs and complementation of nutrients that could be covered up by the pond productivity (Molina-Poveda et al., 2013). The current study was done in cages on earthen ponds and the presence of natural food probably was well accounted for. In the current study, we added three replicates of unfed groups of Nile 
tilapia to estimate CNP. The values of CNP in the Aklan trial were not significantly different among treatments but in the Pangasinan trial, there were significant differences between the dietary groups i.e., the CNP of the CM diet group was significantly higher (38.9\%) than those of CM or CO group $(26.1 \%$ and $24.9 \%$, respectively) $(p<0.05)$. This could be the result of both dietary treatment and the increased stocking density. Previous studies suggested that feeds with a lower biological value can be enhanced by consuming natural productivity present in the earthen pond (Molina-Poveda et al., 2013; Moorthy and Altaff, 2002). In the current study, the CM diet probably contained high inclusion of plant materials lowering its biological value to the fish and the resulting increased CNP became only apparent at a high stocking density in the Pangasinan trial. This is in contrast with the hypothesis of Lawrence \& Houston (1993) that conceptually, as the stocking densities increased, the percentage contribution of natural productivity to the nutritional requirements of the aquatic animal would decrease. These same authors have also found that natural food contributed significantly (77-83\%) to shrimp growth when using vegetable ingredients such as rice and wheat bran and soybean meal without marine meals.

Feed cost decreased as the result of decreased feed consumption (i.e., decreased TFI and DFI) with FCR not a factor in the present study. It is now a common knowledge in animal nutrition that an energy-dense diet results in decreased consumption rate due to the early satisfaction of the animal's energy requirement. FC represents the major proportion of total production cost. When stocking density was increased as that in the Pangasinan trial, fish stock cost increased and FC also increased following the increase of stocking density and fish growth. Thus, increasing stocking density boosted P but limited $\mathrm{Pm}$ in the current study. It is clear that FC was the only cost that mattered in the present study representing $71.2 \%$ and $65.1 \%$ in the Aklan and Pangasinan trials, respectively. Total production cost decreased in the RLP group following the decrease in FC but the GI was similar with that of the CM group; however, because of the decreased FC in the RLP group, $\mathrm{P}$ and $\mathrm{Pm}$ were as high as 1.93- and 1.88-fold increase, respectively, over that of the CM group in the Aklan trial. In a higher stocking density (Pangasinan trial), P over the lower stocking density was 2.2-fold higher but the Pm was 2.57 -fold lower than that of the Aklan trial.

In conclusion, at 17 fish $\mathrm{m}^{-2}$ stocking density, no significant differences in the parameters were observed except in AGR in which the RLP dietary treatment exhibited a higher value than did either the commercial (CM) diet or the control (without Rhizoclonium) (CO) diet. At a higher stocking density of 27 fish. $\mathrm{m}^{-2}$, significant differences in TFI, DFI and SGR were observed, all the other parameters were similar. The RLP group exhibited lower TFI and DFI but higher SGR than did either the CM or CO diet. In either stocking densities, feed cost was the main determinant of profitability in which the RLP group resulted in significantly the highest profitability i.e., lowest total production cost, highest gross income and highest profit and profit margin. Although profit was significantly higher in the higher stocking density, profit margin was significantly higher in the lower stocking density. There was no statistical interaction between dietary treatment and stocking density as analyzed by two-way ANOVA.

\section{Acknowledgements}

The authors would like to thank the Philippine Council for Agriculture, Aquatic and Natural Resources Research and Development (PCAARRD) of the Department of Science and Technology (DOST) for the research grant; the Office of the Vice-Chancellor of Research and Extension of the University of the Philippines Visayas (UPV-OVCRE) for the publication grant. The authors are also grateful to Mr. Ricardo de Guzman and Mr. Lemark Bautista of the Pangasinan State University-Binmaley Campus for technical assistance; to Mr. Arturo Tumbokon and Ms. Lian Pamatian from Lezo, Aklan for technical assistance.

\section{References}

The Israeli Journal of Aquaculture - Bamidgeh • IJA.73.2021.1231673 
Berger, S., Kaever, M.J., 1992. Dasycladales: an illustrated monograph of a fascinating algal order. Stuttgart: Georg Thieme Verlag.

Bunda M.G.B., Tumbokon, B.L.M., Serrano Jr., A. E., 2015. Composition, chemical score (CS) and essential amino acid index (EAAI) of the crinkle grass Rhizoclonium sp. as ingredient for aquafeeds. AACL Bioflux 8(3):411-420.

Cabanero, P.C., Tumbokon, B.L.M., Serrano Jr., A.E., 2016a. Nutritional evaluation of Rhizoclonium riparium var implexum meal to replace soybean in the diet of Nile tilapia fry. The Israeli Journal of Aquaculture - Bamidgeh, IJA_68.2016.1278, 8 pages.

Cabanero, P.C., Tumbokon, B.L.M., Serrano Jr., A.E., 2016a. Lysine supplementation of the protein concentrate of crinkle grass Rhizoclonium riparium var implexum as an ingredient in the diet of Nile tilapia fry. The Israeli Journal of Aquaculture - Bamidgeh, IJA_68.2016.1280, 7 pages.

Carneiro, W.F., Colpini, L.M.S., de Souza, R.C.T., Bombardelli, R.A., Balen, R.E., Meurer, F., 2020. Effect of the digestible protein-energy relationship on the growth performance of Nile tilapia (Oreochromis niloticus) fed fishmeal-free diets. Animal Feed Science and Technology 262: 114379. https://doi.org/10.1016/j.anifeedsci.2019.114379. Chao, K.-P., Chen, C.-S., Wang, E.I.-C., Su, Y.-C., 2005. Aquacultural characteristics of Rhizoclonium riparium and evaluation of its biomass growth potential. J. App. Phycol., 17: 67-73.

De la Higuera, M., 2001. Effects of Nutritional Factors and Feed Characteristics on Feed Intake. Food Intake in Fish. Blackwell Science Ltd, Oxford, UK, pp. 250-268.

https://doi.org/10.1002/9780470999516.ch11.

De Silva, S.S., Gunasekera, R.M., Shim, K.F., 1991. Interactions of varying dietary protein and lipid levels in young red tilapia: evidence of protein sparing. Aquaculture 95, 305-318. https://doi.org/10.1016/0044-8486(91)90096-P.

El-Sayed, A.-F.M., Teshima, S., 1992. Protein and energy requirements of Nile tilapia, Oreochromis niloticus, fry. Aquaculture 103, 55-63. https://doi.org/10.1016/00448486(92)90278-S.

FAO, 2018. Fishery and Aquaculture Statistics Statistiques des pêches et de I' aquaculture Estadísticas de pesca y acuicultura, Fao. https://doi.org/10.5860/CHOICE.50-5350.

Fernandes, A.C., de Carvalho, P.L.P.F., Pezzato, L.E., Koch, J.F.A., Teixeira, C.P., Cintra, F.T., Damasceno, F.M., Amorin, R.L., Padovani, C.R., Barros, M.M., 2016. The effect of digestible protein to digestible energy ratio and choline supplementation on growth, hematological parameters, liver steatosis and size-sorting stress response in Nile tilapia under field condition. Aquaculture 456, 83-93. https://doi.org/10.1016/j.aquaculture.2016.02.001.

Haidar, M.N., Bleeker, S., Heinsbroek, L.T.N., Schrama, J.W., 2018. Effect of constant digestible protein intake and varying digestible energy levels on energy and protein utilization in Nile tilapia. Aquaculture 489, 28-35. https://doi.org/10.1016/j. aquaculture.2017.12.035.

Imai M., Katayama, N., Yamaguchi, Y., 1997. Effects of salinity on growth, photosynthesis and respiration in a freshwater alga Rhizoclonium riparium (Chlorophyceae, Cladophorales). Phycological Research, 45: 233-237. https://doi.org/10.1111/j.14401835.1997.tb00082.x

Kabir, K.A., Verdegem, M.C.J., Verreth, J.A.J., Phillips, M.J., Schrama, J.W., 2019a. Effect of dietary protein to energy ratio, stocking density and feeding level on performance of Nile tilapia in pond aquaculture. Aquaculture 511: 634200. 9 pages. https://doi.org/10.1016/j.aquaculture.2019.06.014

Kabir, K.A., Schrama, J.W., Verreth, J.A.J., Phillips, M.J., Verdegem, M.C.J., 2019b. Effect of dietary protein to energy ratio on performance of nile tilapia and food web enhancement in semi-intensive pond aquaculture. Aquaculture 499, 235-242. https:// doi.org/10.1016/j.aquaculture.2018.09.038.

Kaushik, S.J., Doudet, T., Medale, F., Aguirre, P., Blanc, D., 1995. Protein and energy needs for maintenance and growth of Nile tilapia (Oreochrornis niloticus). J. Appl. Ecol. 11, 290-296. https://doi.org/10.1111/j.1439-0426.1995.tb00029.x. 
Kim, J.D., Kaushik, S.J., 1992. Contribution of digestible energy from carbohydrates and estimation of protein/energy requirements for growth of rainbow trout (Oncorhynchus mykiss). Aquaculture 106, 161-169. https://doi.org/10.1016/0044-8486(92)90200-5.

Koch, J.F.A., Barros, M.M., Teixeira, C.P., Carvalho, P.L.P.F., Fernandes Junior, A.C., Cintra, F.T., Pezzato, L.E., 2017. Protein-to-energy ratio of $21.43 \mathrm{~g} \mathrm{MJ}^{-1}$ improves growth performance of Nile tilapia at the final rearing stage under commercially intensive rearing conditions. Aquac. Nutr. 23, 560-570. https://doi.org/10.1111/anu.12423.

Lawrence, A.L., Houston, D.M., 1993. Nutritional response of juvenile Penaeus setiferus and Penaeus vannamei to different quality feeds in the presence and absence of natural productivity. In: McVey, J.P., Collie, M. (Eds.), Proc. 20th US-JAPAN Symposium on Aquaculture Nutrition, pp. 113-124.

Meurer, F., Hayashi, C., Boscolo, W.R., Santos, L.Ddos, Wolf, L., Colpini, L.M.S., 2007. Exigência de Proteína Digestível para Juvenis de Tilápia do Nilo (Oreochromis niloticus) em Baixa Temperatura. Revista científica de produção animal. Revista Científica de Produção Animal 9, 53-64.

Meyer, G., Fracalossi, D.M., 2004. Protein requirement of jundia fingerlings, Rhamdia quelen, at two dietary energy concentrations. Aquaculture 240, 331-343. https://doi.org/10.1016/j.aquaculture.2004.01.034.

Molina-Poveda, C., Lucas, M., Jover, M., 2013. Evaluation of the potential of Andean lupin meal (Lupinus mutabilis Sweet) as an alternative to fish meal in juvenile Litopenaeus vannamei diets. Aquaculture 410-411: 148-156.

Moorthy, M.S., Altaff, T.N., 2002. Role of natural productivity in modified extensive shrimp pond growing Penaeus monodon (Penaeid, Crustacea). Indian Journal of Marine Sciences 312, 195-200.

NRC, 1993. Nutrient Requirements of Fish and Shrimp. National Academies Press, Washington, DC.

NRC, 2011. Nutrient Requirements of Fish and Shrimp. National Academies Press, Washington, DC.

Porchas-Cornejo, Marco A., Martínez-porchas, Marcel, Martínez-Córdova, Luis R., Ramos-Trujillo, Laida, BarrazaGuardado, Ramón, 2012. Consumption of natural and artificial foods by shrimp (Litopenaeus vannamei) reared in ponds with and without enhancement of natural productivity. Israeli Journal of Aquacultre-Bamidgeh 59 (4), 1-7 (IJA_64.2012.709, 7 pages).

Saravanan, S., Geurden, I., Figueiredo-Silva, A.C., Kaushik, S.J., M.N, Verreth, J.A.J., Schrama, J.W., 2012a. Control of voluntary feed intake in fish: a role for dietary oxygen demand in Nile tilapia (Oreochromis niloticus) fed diets with different macronutrient profiles. British Journal of Nutrition 108, 1519-1529. https://doi.org/10.1017/S0007114511006842.

Saravanan, S., Schrama, J.W., Figueiredo-Silva, A.C., Kaushik, S.J., Verreth, J.A.J., Geurden, I., 2012b. Constraints on energy intake in fish: The link between diet composition, energy metabolism, and energy intake in rainbow trout. PLoS One 7, e34743. https://doi.org/10.1371/journal.pone.0034743.

Tacon, A.G.J., Metian, M., 2015. Feed matters: satisfying the feed demand of aquaculture. Rev. Fish. Sci. Aquac. 23, 1-10. https://doi.org/10.1080/23308249.2014.987209.

Wang, J., Jiang, Y., Li, X., Han, T., Yang, Y., Hu, S., Yang, M., 2016. Dietary protein requirement of juvenile red spotted grouper (Epinephelus akaara). Aquaculture 450, 289294. https://doi.org/10.1016/j.aquaculture.2015.08.007.

Yuan, Y., Yuan, Y., Dai, Y., 2017. Economic Profitability of Tilapia Farming in China. pp. 1253-1264. https://doi.org/10.1007/s10499-017-0111-8. 